\title{
CERVICAL NEURENTERIC CYST: A CASE REPORT
}

\author{
CISTO NEURENTÉRICO CERVICAL: RELATO DE CASO \\ QUISTE NEURENTÉRICO CERVICAL: REPORTE DE UN CASO
}

Sophie d'Herbemont, ${ }^{1}$ Andrés Humberto Morales-Martínez, ${ }^{2}$ ggnacio Pavel Navarro-Chávez ${ }^{1}$

1. Centro Médico Nacional 20 de Noviembre, Instituto de Seguridad Social y Servicios para Trabajadores del Estado, Ciudad de México, México.

2. Hospital San Juan de Dios Caja Costarricense del Seguro Social, San José, Costa Rica.

\begin{abstract}
Objective: Neurenteric cysts account for $0.7-1.3 \%$ of all spinal cord tumors. These rare lesions are composed of heterotopic endodermal tissue. Methods: A 26-year-old woman with a 13-month history of severe cervicalgia and brachial paresthesia. Clinically she had mildbilateral brachial paresis (4/5), generalized hyperreflexia and a left Babinski Sign. Past medical history was significant for a cervical fistula closure when she was 1yearold. The superior somatosensory evoked potentials revealed medullary axonal damage with a left predominance. A cervical magnetic resonance imaging of the neck was performed showing a dorsal homogeneous cystic intradural extramedullary lesion with high signal intensity on T2. Computed tomography revealed a Klippel-Feil syndrome. Results: A posterior laminectomy and surgical excision were performed without complications. Post-operative follow-up showed a complete recovery of arm strength. The histopathological report confirmed the preoperative diagnosis of neurenteric cyst. Most neurenteric cysts are located in the spine, mainly in a ventral position. A total of $95 \%$ of neurenteric cysts are found in the intradural/intramedullary compartment. Symptomatic neurenteric cysts typically appear in the second and third decades of life and are 1.5 to 3 times more common in men. In $50 \%$ of the cases, other vertebral malformations have also been reported. In this case, a congenital dorsal enteric cyst and a Klippel-Feil syndrome were observed. Conclusions: The intraspinal neurenteric cysts are rare lesions that must be included in the differential diagnosis of a dorsal, intradural cystic structure. The diagnosis may be overlooked, especially in cases of chronic neck pain without neurological deficit. Level of evidence V; Expert Opinion.
\end{abstract}

Keywords: Neurenteric Cyst; Neural Tube Defects; Klippel-Feil Syndrome; Cervical Vertebrae.

\section{RESUMO}

Objetivo: Os cistos neurentéricos são responsáveis por 0,7 a 1,3\% de todos os tumores da medula espinhal. Essas lesões raras são compostas por tecido endodérmico heterotópico. Métodos: Uma mulher de 26 anos, com história de cervicalgia ao longo da vida, relatou história de 13 meses de piora da cervicalgia e parestesia braquial. Clinicamente, apresentava paresia braquial bilateral leve (4/5), hiperreflexia generalizada e um sinal de Babinski à esquerda. Na história médica pregressa, história de fechamento de fístula cervical com 1 ano de idade. Durante avaliação neurofisiológica, os potenciais evocados somatos-sensitivos superiores revelaram lesão axonal medular com predomínio à esquerda. Na ressonância magnética cervical, foi evidenciada uma lesão extra medular dorsal cística, intradural homogênea hiperintensa em T2. A tomografia computadorizada evidenciou síndrome de Klippel-Feil. Resultados: A laminectomia posterior e a excisão cirúrgica foram realizadas sem complicações. O acompanhamento pós-operatório mostrou recuperação completa da força dos braços. O laudo histopatológico confirmou o diagnóstico pré-operatório de cisto neurentérico. A maioria dos cistos neurentéricos estão localizados na coluna vertebral, principalmente em posição ventral, sendo 95\% dos cistos neurentéricos encontrados no compartimento intradural e intramedular. Cistos neurentéricos sintomáticos aparecem tipicamente na segunda e na terceira décadas de vida e são 1,5 a 3 vezes mais comuns no sexo masculino. Em 50\% dos casos, eles também foram relatados com outras malformações vertebrais. Neste caso, um cisto entérico dorsal congênito e uma síndrome de Klippel-Feil foram observados. Conclusão: O cisto neurentérico intramedular é uma lesão rara que deve ser conhecida pelo neurocirurgião e incluída no diagnóstico diferencial de lesões císticas intramurais dorsales, pois seu diagnóstico é muitas vezes difícil, especialmente em casos de cervicalgia crônica sem déficits neurológicos. Nível de evidência V; Opinião de Especialista.

Descritores: Cisto Neurentérico; Defeitos do Tubo Neural; Síndrome de Klippel Feil; Vértebras Cervicais.

\section{RESUMEN}

Objetivo: Los quistes neuroentéricos representan del 0,7 al 1,3\% de todos los tumores de la médula espinal. Estas lesiones raras están compuestas de tejido endodérmico heterotópico. Métodos: Una mujer de 26 años con cervicalgia severa de 13 meses de evolución acompañada de parestesia braquial. Clínicamente con paresia braquial bilateral leve (4/5), hiperreflexia generalizada y signo de Babinski izquierdo. En los antecedentes de importancia, le realizaron un cierre de una fístula cervical cuando tenía 1 año. Los potenciales evocados somatosensoriales superiores revelaron daño axonal medular con un predominio izquierdo. Se realizó una resonancia magnética cervical evidenciando una lesión ventral extramedular intradural quística homogénea hiperintensa en T2. La tomografía computarizada reveló un síndrome de Klippel-Feil. Resultados: Se realizó una laminectomía posterior y resección quirúrgica sin complicaciones. El seguimiento postoperatorio mostró una recuperación completa de la fuerza de los brazos. El informe histopatológico confirmó el diagnóstico preoperatorio de quiste neuroentérico. La mayoría de los quistes neuroentéricos se localizan en la columna vertebral, principalmente en una posición ventral. El 95\% de los quistes neuroentéricos se encuentran en el compartimento

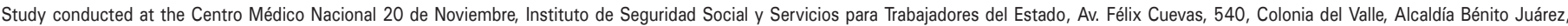
CP. 03100, Ciudad de México, Mexico.

Correspondence: Sophie d'Herbemont. Av. Félix Cuevas, 540, Colonia del Valle, Alcaldía Bénito Juárez, CP. 03100, Ciudad de México, México. 03100. drsoph@me.com 
intradural/intramedular. Los quistes neuroentéricos sintomáticos aparecen típicamente en la segunda y tercera décadas de la vida y son 1.5 a 3 veces más comunes en los hombres. En el 50\% de los casos, también se han notificado otras malformaciones vertebrales. En este caso, se observaron un quiste entérico dorsal congénito y un síndrome de Klippel-Feil. Conclusiones: Los quistes neuroentéricos intraspinales son lesiones poco frecuentes que deben incluirse en el diagnóstico diferencial de una estructura quística intradural en posición dorsal. El diagnóstico puede pasarse por alto, especialmente en caso de dolor cervical crónico sin déficit neurológico. Nivel de evidencia V; Opinión de Especialista.

Descriptores: Quiste Neurentérico; Defectos del Tubo Neural; Síndrome de Klippel-Feil; Vértebras Cervicales.

\section{INTRODUCTION}

Neurenteric cysts account for between 0.7 and $1.3 \%$ of all axial spinal cord tumors. ${ }^{1}$ These are rare lesions composed of heterotopic endodermal tissue. During the third week of embryogenesis the incomplete separation of the notochordal plate and the endoderm produces heterotopic remnants of the gastrointestinal and respiratory epithelium and the possible formation of compressive cystic lesions of the medulla. ${ }^{2-6}$ Classically, neurenteric cysts are reported in locations anterior or anterolateral to the spinal cord. ${ }^{6}$

We present a case of a neurenteric intradural extramedullary cyst of atypical localization due to its location dorsal to the spinal cord, associated with the Klippel-Feil syndrome and a posterior cutaneous cervical fistula treated via posterior approach

\section{CASE DESCRIPTION}

A 26-year-old female with a history of brachial paresthesia and paresis progressing over 13 months with severe headache nonresponsive to medical treatment. The only significant history was the closure of a cervical fistula performed when she was 1 year old. Upon admission, she presented bilateral brachial paresis (4/5 on the Daniels scale) with global hyperreflexia and the Babinski sign on the left side. The neurophysiological study data were compatible with predominantly left-sided axonal medullary damage. Cervical magnetic resonance and cervical computed tomography were performed and revealed an intradural extramedullary cystic lesion located dorsally to the spinal cord, $20.5 \times 12 \times 13.5 \mathrm{~mm}$ in cephalocaudal, anteroposterior, and laterolateral diameters, respectively, of homogeneous isointense behavior in $\mathrm{T} 1$ and hyperintense in T2. (Figure 1) The tomography showed a hemivertebra at level C4. (Figure 2) A posterior C2-C4 laminectomy was performed and both a hemilamina of $\mathrm{C} 4$ and diastematomyelia were found. The dural sac was opened and an outflow of crystal clear cerebrospinal was observed. An neurenteric cyst of pearled appearance with attached wall was discovered. (Figure 3) Drainage and complete resection were performed without complications. (Figure 4) The patient was kept under invasive protection of the airway for 12 hours and then extubated without complications. Following surgery, a rigid Miami J collar was used for 3 months. The patient's pain improved and she recovered strength of the upper extremities (Daniels 5/5). The pathology report confirmed the preoperative diagnosis of a neurenteric cyst.
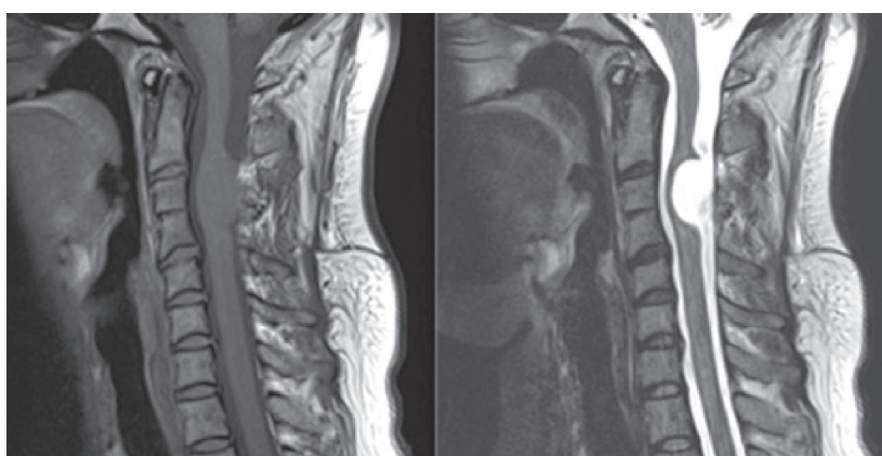

Figure 1. Cervical MRI in T1 and T2. Intradural extramedullary cystic lesion of $20.5 \times 12 \times 13.5 \mathrm{~mm}$ in cephalocaudal, anterposterior, and laterolateral diameters, respectively, homogeneous and isointense in $\mathrm{T} 1$ and hyperintense in $\mathrm{T} 2$.

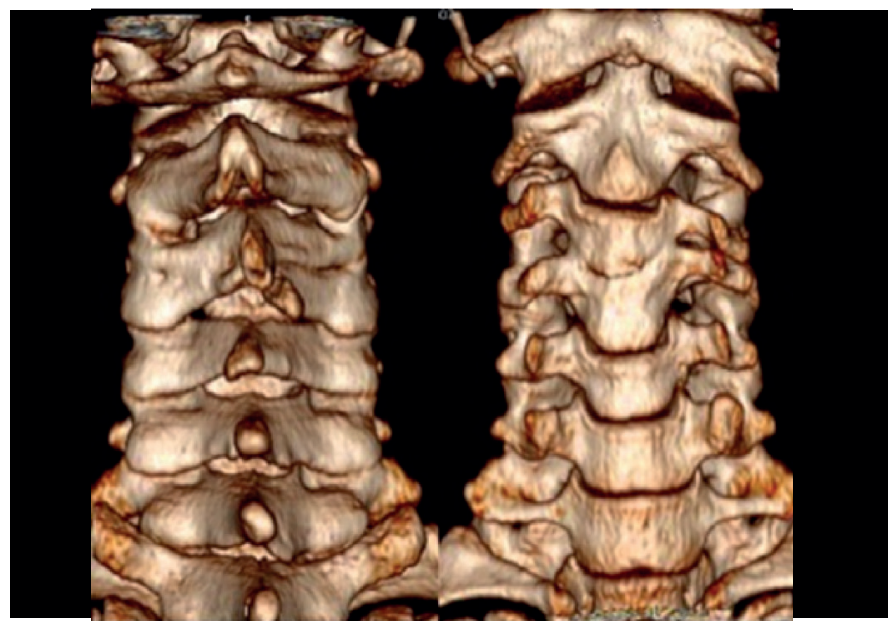

Figure 2. Three-dimensional CT reconstruction of the spine, with evidence of a hemivertebra at the $\mathrm{C} 4$ level.

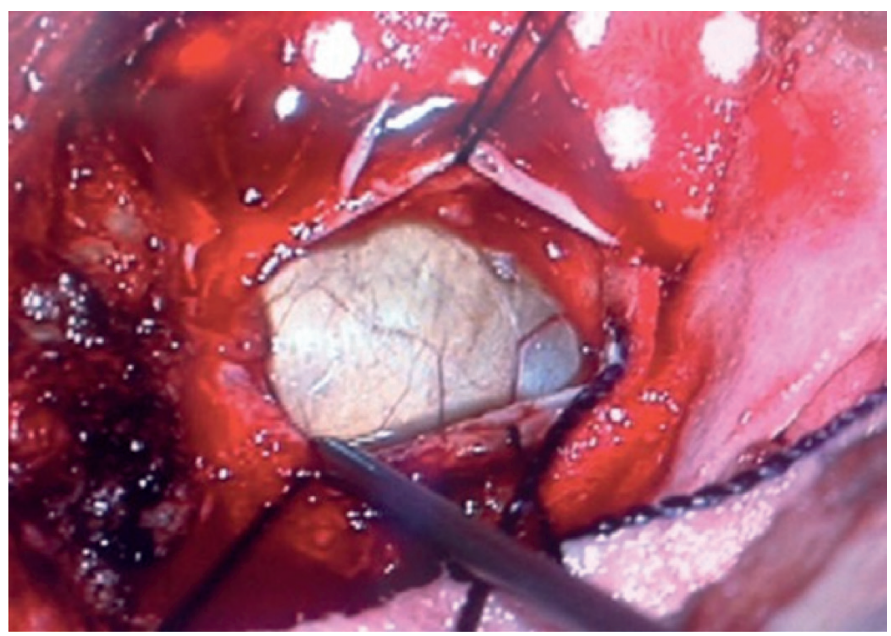

Figure 3. Intraoperative photo in which the pearly enteric cyst is observed.

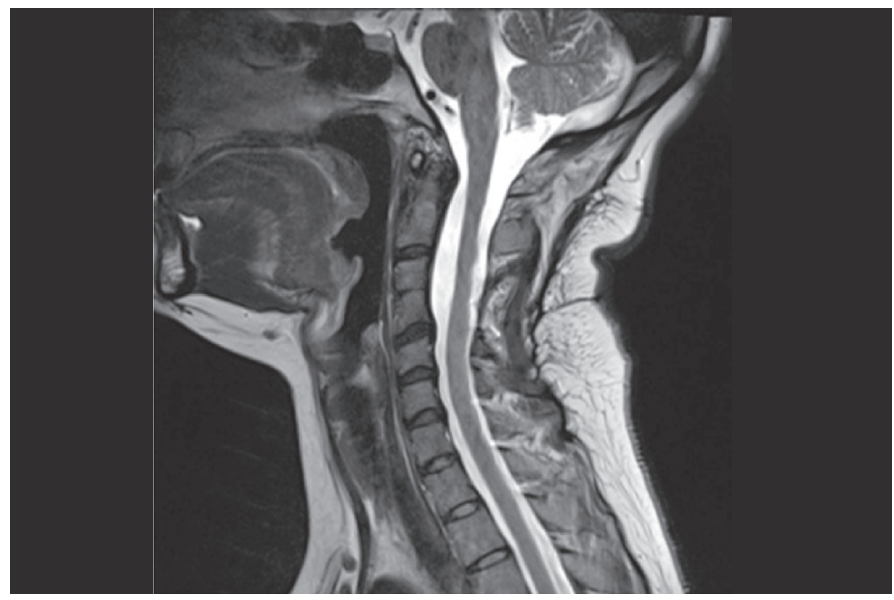

Figure 4. Postoperative cervical MRI in T2. 


\section{DISCUSSION}

Neurenteric spinal cysts are rare congenital lesions that usually manifest in the second or third decade of life and are 1.5 to 3 times more common in men. ${ }^{7}$ They were first described by Kubie and Fulton ${ }^{8}$ in 1928 as teratomatous cysts, their name changed to intestinoma in 1934 by Puusepp, ${ }^{9}$ and later the term neurenteric cyst coined by 1954 by Holcomb and Matson became widely accepted. ${ }^{10}$ Most of the reported cysts are located in the spinal cord, usually ventrally. ${ }^{4,11}$ Ninety-five percent are intradural and extramedullary in the spinal canal, the remaining $5 \%$ being intramedullary. ${ }^{7,12}$ In $50 \%$ of cases, they are accompanied by vertebral abnormalities such as the Klippel-Feil syndrome, spinal defects, and spondylolisthesis. ${ }^{7,13,14}$ In the case presented, it was associated with posterior cutaneous cervical fistula and hemivertebra at level C3-C4.

Neurenteric cysts are congenital by nature. During the third week of gestation, the neuroectoderm does not separate properly from the endoderm, causing the growth of endodermic cells in the neuroaxis and therefore the development of a neurenteric cyst. ${ }^{15}$ In the case presented, the patient underwent surgery to close an enteric cervical fistula when she was one year old, which supports the congenital nature of the condition presented.

Neurenteric cysts are classified into 3 groups according to Wilkens and Odom, 2,4,12 based on the histological findings: Type A, simple or pseudostratified, cuboidal epithelium composed of type IV collagen; Type B, includes the findings for Type A with the presence of glandular tissue, smooth muscle, fat, cartilage, bone, elastic fibers, lymphoid tissue, or nerve ganglia; Type $\mathrm{C}$, includes the findings of Types $\mathrm{A}$ and $B$, with the addition of ependymal or glial tissue. The case presented was representative of a Type A neurenteric cyst.
The clinical presentation involves pain, myelopathy, progressive weakness or sensory dysfunction according to the level affected, but generally insidious. ${ }^{16}$ Imaging studies are important in reaching a diagnosis. In MRls, because of their proteinaceous and mucinous components, they are generally hypo- to isointense in $\mathrm{T} 1$ and hyperintense in T2. The intensity may vary due to cystic and solid components. The lack of enhancement with the administration of contrast and the absence of a nodule attached to the wall may help to distinguish neurenteric cysts from other spinal tumors. Computed tomography of the cervical spine can reveal evidence of bone lesions or associated vertebral abnormalities, as it did in our case..$^{7,13}$

The treatment of choice is complete surgical resection. The reported rate of recurrence is from 0 to $37 \%$ regardless of the level of the lesion. ${ }^{17,18}$ Patient follow-up should be for life, given that the risk of recurrence exists even for decades following a complete resection. $2,7,19,20$

\section{CONCLUSIONS}

Intraspinal neurenteric cysts are rare lesions that should be included in the differential diagnosis of an intradural cystic lesion. The diagnosis of these lesions can be delayed, especially if the patient presents persistent pain without neurological deficit or if the location is atypical. We have presented the case of a dorsally-located neurenteric cervical cyst associated with vertebral abnormality confirmed by histopathology.

All authors declare no potential conflict of interest related to this article.

CONTRIBUTION OF THE AUTHORS: Each author made significant individual contributions to this manuscript. SH (0000-0002-7107-9110)*: surgery, writing of the article, final approval of the version of the manuscript to be published. AHMM (0000-0001-6897-2584)*: critical review of the intellectual content, writing of the article, final approval of the version of the manuscript to be published. IPNC (0000-0003-1863-9112)*: surgery, substantial contribution to the study concept, critical review of the intellectual content, final approval of the version of the manuscript to be published, responsible for all aspects of the study in the sense of ensuring that any issue related to the integrity of accuracy of any part of the study the final will be duly investigated and resolved. ${ }^{*} \mathrm{ORCID}$ (Open Researcher and Contributor ID).

\section{REFERENCES}

1. Fortuna A, Mercuri S. Intradural spinal cysts. Acta Neurochir (Wein). 1983;68(3-4):289-314.

2. Savage J, Casey J, McNeill I, Sherman J. Neurenteric cysts of the spine. J Craniovertebr Junction Spine. 2010:1(1):58-63.

3. Visvanathan V, Crowther J, Taylor W. Neurenteric cyst presenting with stridor and dysphagia: case report and literature review. Scott Med J. 2015;60(1):e4-7.

4. Rollán C, Chaves H, Arakaki N, Yañez P. Quiste neuroentérico de localización atípica con correlación radiológica y patológica. Rev Argent Radiol. 2015;79(3):158-61.

5. Khadim MT, Asif M, Ali Z. Intraspinal Neurenteric Cyst - a rare entity. J Pak Med Assoc. $2011 ; 61(11): 1143-5$

6. Rauzzino MJ, Tubbs RS, Alexander E, Grabb PA, Oakes WJ. Spinal neurenteric cysts and their relation to more common aspects of occult spinal dysraphism. Neurosurg Focus. 2001;10(1):e2.

7. Garg N, Sampath S, Yasha TC, Chandramouli BA, Indira Devi B, Kovoor JME. Is total excision of spinal neurenteric cysts possible? Br J Neurosurg. 2008;22(2):241-51

8. Kubie LS, Fulton JF. A Clinical and pathological study of two teratomatous cyst of the spinal cord, containing mucous and ciliated cells. Surg Gynec Obstet. 1928:47:297-311.

9. Puusepp M. Varieté rare de teratome sous dural de la région cervicale (intestinome) : quadriplégie, extirpation, guérison complete. Rev Neurol. 1934;2:879-86.

10. Holcomb GW, Matson DD. Thoracic neurenteric cyst. Surgery. 1954;35(1):115-21.

11. Salunke P, Rane S, Chhabra R, Savardekar A. Dorsally placed extradural infected neurenteric cyst in a two-year old with paraspinal extension. Neurol India. 2012;60(1):129-31.

12. Jhawar SS, Mahore A, Goel A. Intramedullary spinal neurenteric cyst with fluid-fluid level. J
Neurosurg Pediatr. 2012:9(5):542-5

13. Can A, Dos Santos Rubio EJ, Jasperse B, Verdijk RM, Harhangi BS. Spinal Neurenteric Cyst in Association with Klippel-Feil Syndrome: Case Report and Literature Review. World Neurosurg. 2015;84(2):592.e9-592.e14.

14. Shukla M, Behari S, Das KK, Mehrotra A, Sirvastava AK, Sahu RN, et al. Spinal neurenteric cysts: Associated developmental anomalies and rationale of surgical approaches. Acta Neurochir (Wien). 2015;157(9):1601-10.

15. Gauden AJ, Khurana VG, Tsui AE, Kaye AH. Intracranial neurenteric cysts: a concise review including an illustrative patient. J Clin Neurosci. 2012;19(3):352-9.

16. Chen J, Lai R, Li Z, Gao J, Li Y, Wang T, et al. Case Report Series and Review of Rare Intradural Extramedullary Neoplasms-Bronchiogenic Cysts. Medicine (Baltimore). 2015;94(49):e2039.

17. Sadeghi-Hariri B, Khalatbari MR, Hassani H, Taheri B, Abbassioun K. Intramedullary neurenteric cyst of the conus medullaris without associated spinal malformation: a case report and review of the literature. Turk Neurosurg. 2012;22(4):478-82.

18. Zou M-X, Hu J-R, Kang Y-J, Li J, Lv G-H, She X-L. Bronchogenic cyst of the conus medullaris with spinal cord tethering: a case report and review of the literature. Int $\mathrm{J}$ Clin Exp Pathol. 2015;8(4):3937-42.

19. Yang T, Wu L, Fang J, Yang $C$, Deng $X, X u$ Y. Clinical presentation and surgical outcomes of intramedullary neurenteric cysts. J Neurosurg Spine. 2015;23(1):99-110.

20. Kist E. Recurrent Lumbar Spinal Intradural Enterogenous Cyst: A Case Report. Turk Neurosurg. 2010;20(3):402-5. 